Jurnal Manajemen dan Bisnis, Volume 2, No. 1, Januari 2020

\title{
ANALISIS PERPUTARAN KAS DAN PERUBAHAN PENJUALAN TERHADAP PROFITABILITAS PADA PERUSAHAAN MANUFAKTUR (SEKTOR INDUSTRI MAKANAN DAN MINUMAN) PERIODE 2015 - 2018
}

\author{
Henrych Napitupulu ${ }^{1}$, Andhika Napitupulu ${ }^{2}$ \\ Sekolah Tinggi Ilmu Ekonomi Jayakarta \\ 1) heinrcyh@ stie.jayakarta.ac.id ${ }^{2)}$ andhika@ stie.jayakarta.ac.id
}

\begin{abstract}
This study aims to determine the analysis of cash turnover and sales changes both partially and simultaneously on profitability. The sample selection is done by purposive sampling method and from 6 companies. The research method used in this study is a quantitative method. Statistical testing which is multiple linear regression and data analysis techniques using the classic assumption test. F test results, obtained an F value of 4.887 with a significant level of 0.018 means that simultaneously simultaneous cash turnover and changes in sales have a significant effect on profitability. The t-test results partially indicate the level of significance obtained from the free variable cash turnover of 0.082>0.05, this shows that cash turnover has no significant effect on profitability. While the independent variable sales growth of $0.033<0.05$, this shows that sales growth has a significant effect on profitability
\end{abstract}

Keywords: Cash Turnover, Changes in Sales, Profitability

\begin{abstract}
ABSTRAK
Penelitian ini bertujuan untuk mengetahui analisis perputaran kas dan perubahan penjualan baik secara parsial maupun simultan terhadap profitabilitas. Pemilihan sampel dilakukan dengan metode purposive sampling dan dari 6 perusahaan. Metode penelitian yang digunakan dalam penelitian ini adalah metode kuantitatif. Pengujian statistik yang adalah regresi linear berganda dan teknik analisis data menggunakan uji asumsi klasik. Hasil uji F, diperoleh nilai $\mathrm{F}$ sebesar 4,887 dengan tingkat signifikan 0,018 berarti dengan demikian secara simultan perputaran kas dan perubahan penjualan berpengaruh signifikan terhadap profitabilitas. Hasil uji t secara parsial menunjukkan tingkat signifikansi yang diperoleh dari variabel bebas perputaran kas sebesar 0,082>0,05, hal ini menunjukkan perputaran kas tidak berpengaruh signifikan terhadap profitabilitas. Sedangkan variabel bebas pertumbuhan penjualan sebesar $0,033<0,05$, hal ini menunjukkan bahwa pertumbuhan penjualan berpengaruh signifikan terhadap profitabilitas.
\end{abstract}

Kata-kata Kunci: Perputaran Kas, Perubahan Penjualan, Profitabilitas 
Jurnal Manajemen dan Bisnis, Volume 2, No. 1, Januari 2020

\section{PENDAHULUAN}

Sektor makanan dan minuman di Indonesia memiliki potensi pertumbuhan yang besar karena pada dasarnya Indonesia adalah negara dengan sumber daya pertanian yang berlimpah. Revolusi Industri 4.0 Mengandalkan Internet of Things hal yang berkaitan dengan perangkat fisik, peralatan rumah tangga, software, konektivitas, dan semua barang yang mengadopsi barang elektronik. Barang-barang tersebut terhubung dengan internet dan memungkinkan adanya pertukaran data.

- Sebuah perusahaan pada umumnya memiliki dua jenis aktiva (aset) yaitu aktiva lancar dan aktiva tetap. Kedua unsur struktur ini akan membentuk struktur aktiva. Aktiva lancar adalah harta perusahaan yang dapat dijadikan uang dalam waktu singkat (maksimal satu tahun), komponen aktiva lancar meliputi kas, bank, surat-surat berharga, piutang, persediaan, biaya dibayar dimuka, pendapatan yang masih harus diterima, pinjaman yang diberikan dan aktiva lancar lainnya.

Kas dan piutang memiliki pengaruh yang tinggi terhadap profitabiltas sehingga perlu penanganan yang efektif dan efisien. Tujuan dari kas adalah untuk membiayai operasi perusahaan sehari-hari maupun untuk mengadakan investasi baru dalam aktiva tetap. Tingkat perputaran kas yang tinggi menunjukkan kecepatan arus kas kembali dari kas yang telah diinvestasikan pada aktiva.
Perputaran kas merupakan periode berputarnya kas yang dimulai saat kas diinvestasikan dalam komponen modal kerja sampai saat kembali menjadi kas-kas sebagai unsur modal kerja yang paling tinggi likuiditasnya. Semakin tinggi perputaran kas akan semakin baik, karena ini berarti semakin tinggi efisiensi penggunaan kasnya dan keuntungan yang diperoleh akan semakin besar.

Dalam persaingan usaha yang semakin kompetitif selain kepemilikan aset, perusahaan juga harus mampu bersaing dalam rangka meningkatkan pendapatan. Pendapatan tersebut diperoleh dengan cara meningkatkan penjualan untuk mencapai profit yang diinginkan. Pertumbuhan penjualan mencerminkan tingkat keberhasilan investasi dari periode masa lalu dan dapat digunakan dalam memprediksi pertumbuhan masa yang akan datang. Pertumbuhan penjualan juga merupakan indikator permintaan dan daya saing perusahaan dalam suatu industri.

\section{KAJIAN LITERATUR}

Laporan keuangan pada dasarnya adalah hasil dari proses akuntansi yang dapat digunakan sebagai alat untuk mengkomunikasikan data keuangan atau aktivitas perusahaan kepada pihak-pihak yang berkepentingan. Menurut (Hery, 2017: 12) laporan keuangan (financial statements) merupakan produk akhir dari 
Jurnal Manajemen dan Bisnis, Volume 2, No. 1, Januari 2020

serangkaian proses pencatatan dan mengukur seberapa besar pertumbuhan penjualan pengikhtisaran data transaksi bisnis.

Kas merupakan aset perusahaan yang terdiri dari uang logam, uang kertas, cek, dan simpanan di bank yang dapat dicairkan setiap saat. Menurut James O. Gill (Kasmir, 2018: 120), "Rasio perputaran kas (cash turn over) berfungsi untuk mengukur tingkat kecukupan modal kerja perusahaan yang dibutuhkan untuk membayar tagihan dan membiayai penjualan. "Artinya rasio ini digunakan untuk mengukur tingkat ketersediaan kas untuk membayar tagihan (utang) dan biaya-biaya yang berkaitan dengan penjualan.

Arus kas merupakan salah satu alat untuk mempertahankan kelangsungan hidup sebuah perusahaan. Sebuah perusahaan yang menghasilkan profit yang sangat besar tetapi tidak memiliki arus kas yang tersedia untuk menjalankan kegiatan operasional perusahaan akan terpuruk dan sangat berketergantungan kepada pihak lain. Jadi, perusahaan harus mengelola penggunaan kas dengan baik sehingga jumlah kas perusahaan tidak diinvestasikan ke dalam aset yang tidak penting.

Pertumbuhan penjualan suatu produk sangat tergantung pada daur hidup produk. Jonathan Surya dkk (2016: 107) mengatakan bahwa: Pertumbuhan penjualan adalah kenaikan atau penurunan jumlah penjualan dari tahun ke tahun atau dari waktu ke waktu. Pertumbuhan penjualan (growth) memiliki peranan yang penting dalam manajemen modal kerja. Dengan

dari tahun ke tahun, perusahaan dapat memprediksi seberapa besar profit yang akan didapatkan tiap tahunnya. Dari pengertian diatas dapat disimpulkan tingkat pertumbuhan penjualan merupakan perubahan atau peningkatan penjualan per tahun.

Profitabilitas adalah kemampuan perusahaan memperoleh laba dalam hubungannya dengan penjualan, total aktiva maupun modal sendiri. Profit margin yaitu perbandingan antara net operating income dengan net sales. Menurut Malayu S.P. Hasibuan (2015: 104) Profitabilitas adalah kemampuan bank dalam menghasilkan laba.

Optimalisasi perolehan laba merupakan syarat yang mendasari pengujian menyeluruh terhadap prestasi keuangan perusahaan. akan tetapi jika hanya semata-mata menekankan optimalisasi perolehan laba tanpa memperhatikan tingkat keberhasilan perusahaan dalam mencapai laba tersebut, maka perolehan laba perusahaan belum menjamin bahwa perusahaan telah menjalankan operasional dengan baik. Perusahaan dapat dikatakan sukses apabila mampu menggunakan aktivanya secara produktif dalam mencapai laba untuk mengetahui kesuksesan perusahaan menggunakan aktivanya secara produktif dalam menciptakan laba adalah dengan mengukur tingkat profitabilitasnya.

\section{METODE}


Jurnal Manajemen dan Bisnis, Volume 2, No. 1, Januari 2020

Dalam suatu penelitian seorang peneliti harus menggunakan jenis penelitian yang tepat. Adapun jenis penelitian yang digunakan dalam penelitian ini adalah metode penelitian kuantitatif. Metode penelitian kuantitatif dapat diartikan juga sebagai metode penelitian yang berlandaskan pada filsafat positivisme, digunakan untuk meneliti pada populasi atau sampel tertentu. Penelitian ini menggunakan data sekunder berupa laporan keuangan pada perusahaan-perusahaan manufaktur sektor industri makanan dan minuman yang terdaftar di Bursa Efek Indonesia tahun 2015-2018.

Defenisi operasional variabel adalah suatu definisi yang memberikan arti yang diperlukan untuk mengukur suatu variabel. Variabel terikat yang digunakan dalam penelitian ini adalah profitabilitas. Variabel ini merupakan variabel yang mempengaruhi atau menjadi sebab perubahan variabel dependen (terikat). Variabel independen dalam penelitian ini adalah perputaran kas dan pertumbuhan penjualan.

Populasi dalam penelitian ini adalah semua laporan keuangan tahunan yang diterbitkan oleh Perusahaan Manufaktur Sektor Industri Makanan dan Minuman yang terdaftar di Bursa Efek Indonesia, yaitu berjumlah 6 perusahaan yang terdiri dari neraca dan laba rugi. Teknik sampling yang digunakan untuk penelitian ini adalah Purposive samplig.

\section{HASIL DAN PEMBAHASAN}

Berdasarkan data penelitian yang berasal dari laporan keuangan perusahaan manufaktur sektor industri yang diperoleh dari situs Bursa Efek Indonesia (BEI) www.idx.co.id. Perusahaan yang telah menjadi sampel kemudian dicari nilai total perputaran kas dan perubahan penjualan masing-masing perusahaan.

Hasil dari pengujian statistik deskriptif dari variabel penelitian Perputan Kas dan Perubahan Penjualan pada Profitabilitas dari sampel perusahaan sub-sektor makanan dan minuman tahun 2015-2018.

\begin{tabular}{|l|r|r|r|r|r|}
\hline & D & Minimum & Maximum & Mean & Std. Deviation \\
\hline Perputaran Kas & 24 & 2,00 & 68,00 & 20,0833 & 24,85246 \\
Pertumbuhan & 24 &, 01 &, 24 &, 0919 &, 05496 \\
Penjualan & 24 & 6,67 & 65,80 & 19,2187 & 18,54061 \\
Profitabilitas & 24 & & & & \\
Valid N (listwise) & & & & & \\
\hline
\end{tabular}

Tabel 1. Analisa Deskriptif

1. Variabel Perputaran Kas memiliki mean sebesar 20,0833, standar Deviasi 24,85246, nilai minimum sebesar 2,00, dan nilai maksimum sebesar 68,00 dengan jumlah data yang digunakan seluruhnya sebanyak 24.

2. Variabel Perubahan Penjualan memilki ratarata sebesar 0,0919, standar deviasi 0, 05496, nilai minimum sebesar 0,01 , dan nilai maksimum sebesar 0,24 dengan jumlah data yang digunakan seluruhnya sebanyak 24 .

3. Variabel Profitabilitas memilki rata-rata sebesar 19,2187, standar deviasi 18,54061 nilai minimum sebesar 6,67 , dan nilai 
Jurnal Manajemen dan Bisnis, Volume 2, No. 1, Januari 2020

maksimum sebesar 65,80 dengan jumlah data yang digunakan seluruhnya sebanyak 24 .

Uji Normalitas bertujuan untuk menentukan apakah suatu data telah terdistribusi dengan normal atau tidak. Dengan menggunakan uji kolmogorov-smirnov untuk mengetahui normalitas data dari variabel - variabel penelitian yang digunakan, diperoleh nilai signifikansi variabel.
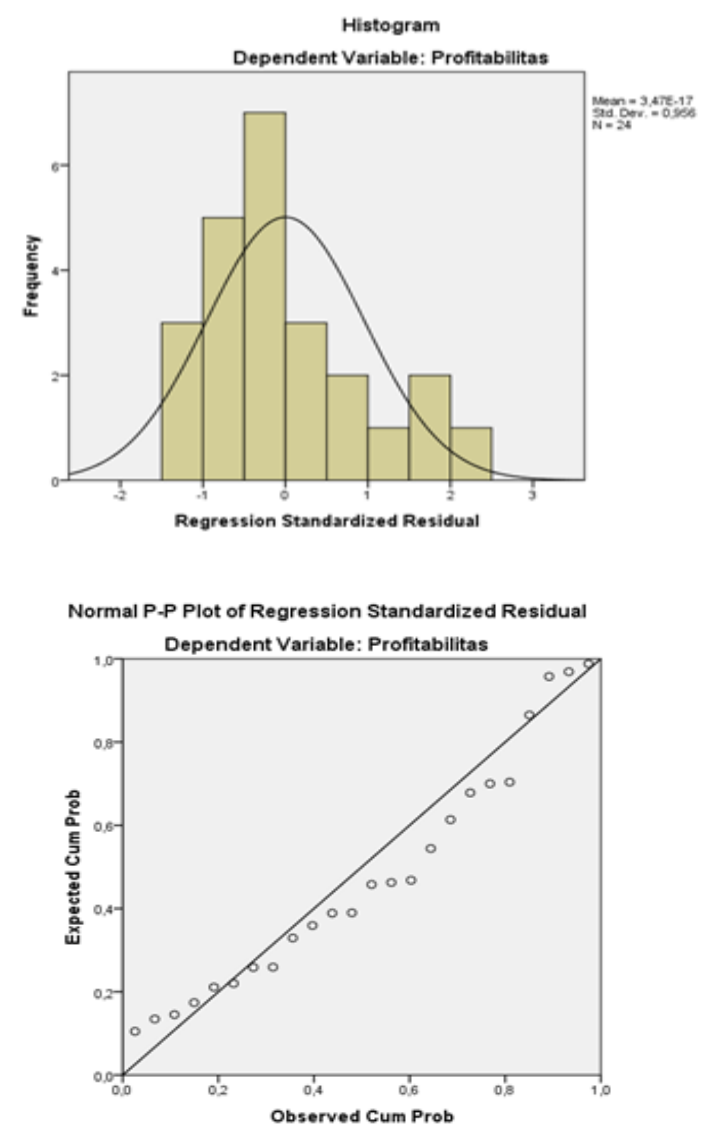

\section{Gamabr 1. Uji Kolmogorov-smirnov}

Pada gambar normal probability plot terlihat sebaran residu berupa dot sebanyak jumlah sampel $=24$ masih berada di sekitar atau tidak jauh dari garis lurus. Hal ini menunjukan distribusi normal.

\begin{tabular}{|c|c|c|c|c|c|c|c|c|}
\hline \multicolumn{9}{|c|}{ Coefficients $^{\mathrm{a}}$} \\
\hline \multirow[t]{2}{*}{ Mode } & & \multicolumn{2}{|c|}{ Unstandardized Coefficients } & \multirow{2}{*}{$\begin{array}{c}\begin{array}{c}\text { Standardized } \\
\text { Coefficients }\end{array} \\
\text { Beta }\end{array}$} & \multirow[t]{2}{*}{$t$} & \multirow[t]{2}{*}{ Sig. } & \multicolumn{2}{|c|}{ Collinearity Statistics } \\
\hline & & $B$ & Std. Error & & & & Tolerance & $\mathrm{VIF}$ \\
\hline \multirow{5}{*}{1} & (Constant) & 37,047 & 6,778 & & 5,466 &, 000 & & \\
\hline & Perputaran &,- 248 & 136 &,- 332 & $-1,828$ &, 082 & ,983 & 1,017 \\
\hline & Kas & & & & & & & \\
\hline & Pertumbuhan & $-139,792$ & 61,320 &,- 414 & $-2,280$ &, 033 &, 983 & 1,017 \\
\hline & Penjualan & & & & & & & \\
\hline
\end{tabular}

a. DependentVariable:Profitabilitas

Tabel 2. Uji t

Berdasarkan tabel di atas nilai t hitung $=$ 1,828. Nilai -1,828<2,0796, dengan demikin Ho ditolak dan $\mathrm{H}_{1}$ diterima, berarti Terdapat pengaruh antara variabel Perputaran $\operatorname{Kas}\left(\mathrm{X}_{1}\right)$ terhadap Profitabilitas (Y). Nilai signifikan Perputaran Kas sebesar 0,082. Nilai 0,082>0,05 berarti tidak terdapat pengaruh antara variabel Perputaran Kas $\left(\mathrm{X}_{1}\right)$ terhadap Profitabilitas (Y).

Hasil penelitian juga menyatakan nilai $t$ hitung $=-2,280$. Nilai $-2,280<2,0796$, dengan demikin Ho diterima dan $\mathrm{H}_{2}$ ditolak, berarti tidak terdapat pengaruh antara variabel Perubahan Penjualan $\left(\mathrm{X}_{2}\right)$ terhadap Profitabilitas $(\mathrm{Y})$. Nilai signifikan Perubahan Penjualan sebesar 0,033. Nilai $0,033<0,05$ berarti terdapat pengaruh negatif antara variabel Perubahan Penjualan $\left(\mathrm{X}_{2}\right)$ terhadap Profitabilitas (Y).

\begin{tabular}{|l|r|r|c|c|c|}
\hline \multicolumn{1}{|l|}{ Model } & \multicolumn{1}{|c|}{$\begin{array}{c}\text { Sum of } \\
\text { Squares }\end{array}$} & df & $\begin{array}{c}\text { Mean } \\
\text { Square }\end{array}$ & F & Sig. \\
\hline Regression & 2510,973 & 2 & 1255,487 & 4,887 &, $018^{\circ}$ \\
$1 \quad$ Residual & 5395,376 & 21 & 256,923 & & \\
Total & 7906,349 & 23 & & & \\
\hline
\end{tabular}
a. Dependent Variable: Profitabilitas
b. Predictors: (Constant), Pertumbuhan Penjualan, Perputaran Kas

\section{Tabel 3. Uji F}

Berdasarkan tabel di atas nilai $\mathrm{F}$ hitung = 4,887. nilai 4,887 > 3,42 dengan demikin Ho 
Jurnal Manajemen dan Bisnis, Volume 2, No. 1, Januari 2020

ditolak dan $\mathrm{H}_{\mathrm{a}}$ diterima, berarti Terdapat pengaruh antara Perputaran Kas $\left(\mathrm{X}_{1}\right)$ dan Perubahan Penjualan $\left(\mathrm{X}_{2}\right)$ secara simultan terhadap Profitabilitas perusahaan yang terdaftar di Bursa Efek Indonesia Tahun 2015-2018 (Y). Nilai Probabilitas sebesar 0,018. Nilai 0,018 < 0,05 berarti Terdapat pengaruh antara Perputaran Kas $\left(\mathrm{X}_{1}\right)$ dan Perubahan Penjualan $\left(\mathrm{X}_{2}\right)$ secara simultan terhadap Profitabilitas (Y).

\section{PENUTUP}

\section{Kesimpulan}

Berdasarkan hasil pengelolahan data dan interpretasi pada masing-masing variabel yang dianalisis dapat disimpulkan sebagai berikut:

1. Terdapat pengaruh signifikan antara perputaran kas terhadap laba bersih. Hal ini dibuktikan dari hasil penelitian:

a. Nilai -t hitung < -t tabel atau $-1,828<$ 2,0796 maka dapat dapat disimpulkan bahwa $\mathrm{H}_{0}$ ditolak dan $\mathrm{H}_{\mathrm{a}}$ diterima. Hal ini berarti bahwa "Perputaran Kas berpengaruh signifikan terhadap Profitabilitas".

b. Nilai probabilitas atau signifikansi $<\mathbf{0 , 0 5}$ atau 0,082 > 0,05 maka Perputaran Kas tidak berpengaruh signifikan terhadap Profitabilitas.

2. Terdapat pengaruh signifikan antara perputaran piutang terhadap laba bersih. Hal ini dibuktikan dari hasil penelitian:

a. Nilai t hitung > t tabel atau $-2,280<$ 2,0796 maka dapat dapat disimpulkan bahwa $\mathrm{H}_{0}$ ditolak dan $\mathrm{H}_{\mathrm{a}}$ diterima. Hal ini berarti bahwa "Perubahan Penjualan berpengaruh signifikan terhadap Profitabilitas"

b. Nilai probabilitas atau signifikansi $<\mathbf{0 , 0 5}$ atau $0,033<0,05$ maka Perubahan Penjualan berpengaruh signifikan terhadap Profitabilitas.

3. Secara simultan perputaran kas dan perputaran piutang berpengaruh signifikan terhadap laba bersih. Hal ini dibuktikan dari hasil penelitian:

a. Nilai $\mathbf{F}$ hitung $>$ F tabel atau 4,887 > 3,42 maka dapat disimpulkan bahwa kedua variabel bebas (Perputaran Kas dan Perubahan Penjualan) secara simultan berpengaruh terhadap variabel terikat Profitabilitas.

b. Nilai probabilitas atau signifikansi $<\mathbf{0 , 0 5}$ atau $0,018<0,05$, maka Perputaran Kas dan Perubahan Penjualan secara simultan berpengaruh terhadap Profitabilitas.

\section{Saran}

Berdasarkan kesimpulan yang diperoleh, maka penulis memberikan saran sebagai berikut:

1. Pentingnya pengelolaan keuangan dalam perputaran kas suatu perusahaan untuk mengukur tingkat ketersediaan kas dan untuk membayar tagihan (utang) juga biaya-biaya yang berkaitan dengan penjualan, maka perusahaan harus bisa mengelola keuangan dengan sebaik-baiknya.

2. Bagi Perusahaan, sebaiknya memerhatikan pengelolaan kas dan penjualan dengan memerhatikan perputaran kas dan pertumbuhan penjualan agar lebih efektif dan 
Jurnal Manajemen dan Bisnis, Volume 2, No. 1, Januari 2020

efisien sehingga bisa mencapai profit yang maksimal.

3. Bagi akademisi, diharapkan untuk mempelajari lebih banyak lagi referensi mengenai faktor-faktor yang dapat mempengaruhi Profitabilitas sehingga tidak bertumpu pada hasil penelitian ini saja. Karena penelitian ini hanya terbatas pada kajian empiris tentang pengaruh perputaran kas dan perubahan penjualan pada perusahaan sektor barang konsumsi.

4. Bagi peneliti selanjutnya, dapat menggunakan variabel bebas yang berbeda seperti perputaran persediaan yang belum digunakan dalam penelitian ini

\section{DAFTAR PUSTAKA}

Damanik, Melani. 2017. "Pengaruh Perputaran Kas dan Perputaran Piutang dalam Meningkatkan Laba Bersih pada PT Indofood Suka Makmur Tbk." Jurnal, Fakultas Ekonomi Bisnis Islam, Universitas Islam Negeri, Medan, Sumatera Utara.

Dantes, Nyoman. 2012. Metode Penelitian. Yogyakarta: ANDI

Deni, Irman. 2014. "Pengaruh Tingkat Perputaran Kas, Perputaran Piutang dan Perputaran Persediaan terhadap Profitabilitas pada Perusahaan Manufaktur yang terdaftar di BEI". Jurnal, Fakultas Ekonomi, Universitas Maritim Raja Ali Haji (UMRAH).

Effendi, Rizal. 2015. Accounting Principles: PrinsipPrinsip Akuntansi Berbasis SAK-ETAP. Jakarta: PT Raja Grafindo Persada.

Ghozali, Imam. 2016 Aplikasi Analisis Multivariate dengan Program IBM SPSS 23. Semarang: Badan Penerbit Universitas Diponegoro.

Hery. 2016. Akuntansi Dasar 1 \& 2. Jakarta: PT Gramedia Widiasarana Indonesia.
Hery. 2016. Analisis Laporan Keuangan. Jakarta: PT Gramedia Widiasarana Indonesia.

Hery. 2016. Mengenal dan Memahami Dasar-Dasar Laporan Keuangan. Jakarta: PT Gramedia Widiasarana Indonesia.

Hery. 2017. Akuntansi Pengantar: Bank Soal dan Solusi. Jakarta: PT Gransindo, Anggota IKAPI.

Hery, 2018. Analisis Laporan Keuangan: Integrated and Comprehensive Edition. Jakarta: PT Grasindo, Anggota IKAPI.

Ikhsan, Arfan.et.al., 2016. Analisa Laporan Keuangan. Medan: Madenatera.

Ikatan Akuntansi Indonesia. 2017. Standar Akuntansi Keuangan. Jakarta: Salemba Empat.

Kasmir, 2018. Analisis Laporan Keuangan. Jakarta: PT Raja Grafindo Persada.

Lestari, Arum Puji Tri. 2017. "Pengaruh Perputara Kas, Perputaran Persediaan dan Perputara Piutang terhadap Profitabilitas pada Perusahaan Manufaktur yang terdaftar di BEI". Jurnal, Fakultas Ekonomi, Universitas Negeri Yogyakarta.

Listyawan, Bayu. 2017. "Pengaruh Struktur Modal, Likuiditas, Ukuran Perusahaan, Pertumbuhan Laba dan Profitabilitas terhadap Kualitas Laba, Studi Empiris pada Perusahaan Manufaktur yang terdaftar di BEI". Jurnal, Fakultas Ekonomi dan Bisnis, Universitas Muhammadiyah Surakarta.

Agustin, Ni Made Dwi, et al. 2014. "Pengaruh Perputaran Kas dan Piutang terhadap Profitabilitas Ekonomis pada Koperasi". Jurnal, Fakultas Ekonomi, Universitas Pendidikan Ganesha, Singaraja, Bali.

Pramiarsih, Euis Eka. 2016. Buku Ajar Akuntansi Keuangan 1. Sleman, Yogyakarta: CV Budi Utama.

PSAK. 2017. Standar Akuntansi Keuangan. Jakarta: Ikatan Akuntan Indonesia (IAI).

Samryn L.M, 2016. Pengantar Akuntansi: Buku 2 Metode Akuntansi untuk Elemen Laporan Keuangan. Jakarta: PT Raja Grafindo Persada.

Silaen, Sofar. 2018. Metodologi Penelitian Sosial untuk Penulisan Skripsi dan Tesis. Bogor: In Media. 
Jurnal Manajemen dan Bisnis, Volume 2, No. 1, Januari 2020

Sugiyono. 2016. Metode Penelitian Kuantitatif

Kualitatif dan R\&D. Bandung: CV Alfabeta.

Sujarweni, V. Wiratna. 2016. Pengantar Akuntansi. Yogyakarta: Pustaka Baru Press.

Sumarsan, Thomas. 2018. Akuntansi Dasar dan Aplikasi dalam Bisnis Versi IFRS. Jilid 2. Jakarta Barat: PT Indeks.

Usman, Sarah. 2017. Perencanaan dalam Keuangan Perusahaan. Sleman, Yogyakarta: CV Budi Utama.

Widasari, Merin. 2016. "Pengaruh Tingkat Perputaran Kas, Perputaran Piutang, Perputaran Persediaan dan Perputaran Aktiva Tetap terhadap Profitabilitas pada Perusahaan Industri Barang Konsumsi yang terdaftar di BEI". Jurnal, Fakultas Ekonomi, Universitas Nusantara Persatuan Guru Republik Indonesia, Kediri.

Weygandt, Kimmel and Kieso. 2015. Financial Accounting: IFRS Edition. Hoboken: John Wiley \& Sons, Inc.

Yuniarwati, Linda Santioso. 2018. Agustin Ekadjaja, Rosmita Rasyid, Pengantar Akuntansi 1: Belajar Mudah Akuntansi. Tajur, Ciledug, Kota Tangerang: PT Pustaka Mandiri, Anggota IKAPI. 